DOI: https://doi.org/10.24144/2409-6857.2020.2(56).81-88

УДК 338(1-32)(477.87):330.59:316.347:37

Сочка К.А., Сембер С.В.

\title{
ЯКІСТЬ ЖИТТЯ НАСЕЛЕННЯ ПОЛІЕТНІЧНОГО РЕГІОНУ ЧЕРЕЗ ПРИЗМУ РІВНЯ ОСВІТИ (НА ПРИКЛАДІ ЗАКАРПАТСЬКОЇ ОБЛАСТІ, УКРАЇНА) ${ }^{1}$
}

\begin{abstract}
У статті досліджено окремі підходи до визначення якості життя, вивчено вибрані глобальні рейтинги, пов'язані з оцінкою якості життя та місце Украйни в них. 3 метою оцінки впливу рівня освіти на окремі показники якості життя у поліетнічному регіоні (Закарпатська область), на основі анкетування проаналізовано вибрані об 'єктивні і суб'єктивні показники освіти респондентів різних національностей. Досліджено вплив рівня освіти на суб'єктивне сприйняття респондентами окремих аспектів якості життя, зокрема, задоволеність рівнем освіти, станом здоров'я, суспільним життям, роботою, рівнем доходів та фінансовим становищем. Запропоновано окремі напрями підвищення впливу освіти на задоволеність якістю життя у поліетнічних регіонах.
\end{abstract}

Ключові слова: поліетнічний регіон, якість життя, рівень освіти, вікова та статева структура респондентів, складові якості життя, доходи, зайнятість

Постановка проблеми. В умовах трансформації економічних та політичних відносин, посилення соціальних та фінансовоекономічних проблем у суспільстві, масової трудової міграції, зниження рівня доходів, глобальних соціально-економічних та екологічних викликів, забезпечення гідного рівня якості життя населення є актуальним завданням, яке постає перед усіма країнами. Передумовами сучасного етапу розвитку суспільства $\epsilon$ максимальна реалізація потенціалу людського ресурсу - забезпечення високого рівня фахової освіти, відповідних інтелектуальних та моральних принципів, процесів постійного самовдосконалення, самопізнання та підвищення професійного рівня, креативність та реалізація підприємницьких здібностей, набуття нових компетенцій. Саме тому в умовах постіндустріального суспільства, динамічного розвитку нових технологій, появи нових сегментів у сфері послуг, поступового зміщення

(C) Сочка К.А., к.е.н., доцент кафедри фінансів і банківської справи ДВНЗ «УжНУ», м. Ужгород, тел. 0975663557, e-mail: kateryna.sochka@uzhnu.edu.ua

Сембер C.В., к.е.н., доцент, Директор Закарпатського регіонального центру соціальноекономічних та гуманітарних досліджень НАН України, доцент кафедри фінансів і банківської справи ДВНЗ «УжНУ», м. Ужгород, тел. 0505330491, e-mail: stepan.sember@uzhnu.edu.ua

${ }^{1}$ Стаття написана за результатами виконання проекту «Якість життя населення регіону в етнодемографічному вимірі» цільової програми наукових досліджень НАН України «Становлення нової якості життя» (2019 р.). акценту на розвиток інформаційного суспільства, підвищення рівня життя населення, великої ваги набуває задоволення різноманітних потреб людини та підвищення якості її життя.

Однією 3 основних складових, що характеризує якість життя населення, є освіта. Здобуття певного рівня освіти формує професійні, інтелектуальні та особистісні характеристики особи, які безумовно, у подальшому впливають на усі аспекти життя людини. У наукових публікаціях українських та зарубіжних дослідників подається різний перелік індикаторів для оцінки зазначеної сфери, залежно від підходів, які покладені в основу конкретних методик. Закарпатська область традиційно характеризується багатонаціональним складом населення, яке сторіччями спільно проживало на території регіону. Для вироблення дієвих заходів у соціально-економічного розвитку області важливо розуміти вплив рівня освіти на компоненти якості життя окремих етнічних груп, які спільно мешкають в одному соціокультурному та економічному середовищі.

Аналіз останніх досліджень та публікацій. Концепція якості життя - надзвичайно комплексне та багатогранне поняття, що $\epsilon$ предметом вивчення різних наук (соціологія, психологія, економіка, медицина, екологія тощо). Зарубіжні дослідники [1, p. 244] наголошують на тому, що якість життя є дуже суб'єктивним, індивідуалізованим показником, який визначається сприйняттям особою свого місця у суспільстві, залежить від культури, системи цінностей, відношення до своїх цілей, очікувань та стандартів особи, особистих вірувань, соціальних взаємовідносин 3 основними елементами середовища, де особа проживає. 
Окремі автори пропонують різні критерії щодо оцінювання якості життя, зокрема, науковець [2] здійснює оцінку якості життя за групами індикаторів, що відображають задоволення основних матеріальних та соціальних потреб фізичний та матеріальний добробут; відносини 3 іншими людьми; соціальна, громадська та суспільна активність; особистий розвиток та досягнення; рекреація.

Колективом авторів [3, p. 12] узагальнено існуючі теоретичні підходи зарубіжних дослідників до оцінки якості життя з урахуванням окремих іiї індикаторів та запропоновано наступні узагальнені групи моделей оцінювання якості життя: моделі, базовані на об‘єктивних індикаторах, які включають стандарти життя, здоров"я та тривалість життя, умови проживання та характеристика громади; моделі, основані на суб“єктивних індикаторах (рівень задоволення життям та психологічне благополуччя, мораль, особисті досягнення, щастя); основані на задоволенні потреб особи (базуються на об‘єктивних умовах (умови проживання, безпека, харчування) та можливостях для самоактуалізації); психологічні моделі (наголошується на важливості особистого розвитку, ефективності та здатності пристосовуватися, почутті власної гідності, незалежності, соціальній компетентності); моделі здоров'я та діяльності; моделі соціального добробуту (вимірюються показниками соціальної співпраці, підтримки, активності, рівнем інтеграції у місцеву громаду); моделі, основані на соціальній згуртованості та соціальному капіталі; моделі, пов'язані з вивченням процесів старіння особи та важливості розробки такого оточення, яке сприяє активній соціальній діяльності осіб похилого віку; індивідуалізований підхід (оснований на цінностях, інтерпретації та очікуваннях особи, iï задоволеністю своїм становищем, умовами та пріоритетами у житті).

Для розуміння порівняльного рівня розвитку людських ресурсів в Україні та інших державах досліджено результати окремих глобальних рейтингів, що оцінюють певні аспекти якості життя.

Відповідно до результатів глобального індексу людського розвитку ООН за 2019 рік (Human Development Index) [4] Україна зайняла 88 місце 3 189 країн. Зазначений Індекс людського розвитку $\epsilon$ підсумковим показником для оцінки довгострокового прогресу в трьох основних сферах людського розвитку - здорове життя, доступ до знань та гідний рівень життя.

Індекс добробуту (Legatum Prosperity Index) оцінюється за 9 складовими, однією 3 яких $є$ освіта. На жаль, за даним індексом Україна у 2019 році посіла тільки 96 місце з 167 країн, при цьому оцінка за компонентою освіти є досить високою 37 місце [5]. Саме досить високі індикатори сфери освіти сприяють підвищенню загального місця України в глобальних рейтингах якості життя.

У багатьох вітчизняних дослідженнях якості життя населення акцент також робиться на вивченні доступності та якості освіти, як невід“ємної компоненти цього поняття.

У Національній доповіді про стан i перспективи розвитку освіти в Україні $[6$, с. 4] наголошується, що традиційно головним рушієм змін та розвитку $\epsilon$ люди, при цьому у ефективному розвитку людського капіталу ключову роль відіграє освіта. Саме тому сьогодні освіта вважається одним 3 чинників та умовою розвитку суспільства.

У дослідженні колективу авторів [7, с. 20] при аналізі існуючих підходів до вимірювання якості життя у різних країн одним з базових індикаторів також зазначено саме освіту. У пропонованій Національній матриці індикаторів якості життя населення в Україні [7, с. 28] субсередовище «освіта» оцінюється у розрізі об“єктивних показників системи освіти та освіти населення, а також суб'єктивної оцінки системи освіти.

У публікації [8, с. 120] автор включає сферу освіти до більш загальної компоненти соціальнокультурних індикаторів якості життя населення.

Підсумовуючи вищезазначене, слід наголосити, що якість та доступність освіти у широкому сенсі $\epsilon$ важливим чинником формування основи для подальшої реалізації особою свого потенціалу.

Цілі та методика дослідження. У вітчизняних дослідженнях якості життя населення поліетнічних регіонів недостатньо висвітлено вплив рівня освіти на задоволення об'єктивних та суб'єктивних індикаторів якості життя різних національностей.

Метою даного дослідження є оцінка рівня освіти окремих національностей Закарпатської області та її вплив на вибрані об'єктивні та суб'єктивні індикатори якості життя цих етнічних груп.

Опитування представників окремих національностей Закарпатської області щодо оцінки якості життя проводилося в рамках виконання проекту «Якість життя населення регіону в етнодемографічному вимірі» цільової програми наукових досліджень НАН України «Становлення нової якості життя» протягом липня - вересня 2019 року шляхом анкетування.

Анкетування проводилося у співпраці 3 національними товариствами Закарпаття культурного та професійного спрямування, серед студентів вищих навчальних закладів регіону - 
представників різних національностей, за допомогою google - форми у мережі Інтернет. Загалом до опрацювання та аналізу прийнято 418 анкет респондентів - репрезентативних представників різних національностей регіону (українці, угорці, румуни, словаки, роми, росіяни, поляки, русини, євреї, чехи, грузини).

У даному дослідженні компонента «освіта», як складова якості життя, оцінюється на основі переліку об'єктивних та суб'єктивних індикаторів, а саме:

- об'єктивними $є$ рівень освіти респондентів (вища, ПТУ або середня спеціальна, загальна середня, початкова освіта, наявність наукового ступеня); участь у навчанні або підвищенні кваліфікації протягом останнього року;

- суб“єктивними визначено рівень задоволення респондента своєю освітою та його середній бал.

3 метою оцінки додаткових чинників впливу компоненти «освіта» на якість життя представників окремих національностей досліджено статеву та вікову структуру респондентів, стан працевлаштування та суб'єктивне сприйняття респондентами з різним рівнем освіти задоволення окремими аспектами життя, такими як рівень освіти, стан здоров'я, суспільне життя, робота, рівень доходів та фінансове становище.

Опис основного матеріалу дослідження. 3 огляду на традиційно багатонаціональний склад населення Закарпаття для вироблення ефективної політики соціального розвитку регіону 3 урахуванням потреб та пріоритетів окремих етнічних груп, важливо розуміти рівень освіти та iii вплив на соціальні та економічні індикатори якості життя.

Аналіз структури вибірки за рівнем освіти засвідчує про досить високий рівень освіти опитаних - більше половини респондентів $(57,66 \%)$ здобули вищу освіту, загальну середню освіту мають $22,0 \%$, ПТУ або середню спеціальну - $14,83 \%$, початкову $-4,07 \%$, науковий ступінь має $1,44 \%$ респондентів (табл. 1.)

Таблиця 1

Національна структура респондентів за рівнем освіти, \%*

\begin{tabular}{|c|c|c|c|c|c|c|}
\hline \multirow[b]{2}{*}{ Національність } & \multicolumn{6}{|c|}{ Рівень освіти } \\
\hline & $\begin{array}{l}\text { Вища } \\
\text { освіта }\end{array}$ & $\begin{array}{l}\text { ПТУ, середня } \\
\text { спеціальна }\end{array}$ & $\begin{array}{l}\text { Загальна } \\
\text { середня }\end{array}$ & $\begin{array}{l}\text { Початкова } \\
\text { освіта }\end{array}$ & $\begin{array}{l}\text { Науковий } \\
\text { ступінь }\end{array}$ & Разом \\
\hline Українці & 61,11 & 14,68 & 22,62 & 0,00 & 1,59 & 100 \\
\hline Угорці & 55,71 & 20,00 & 22,86 & 0,00 & 1,43 & 100 \\
\hline Румуни & 52,00 & 12,00 & 32,00 & 0,00 & 4,00 & 100 \\
\hline Словаки & 80,00 & 13,33 & 6,67 & 0,00 & 0,00 & 100 \\
\hline Роми & 6,67 & 10,00 & 26,67 & 56,67 & 0,00 & 100 \\
\hline Росіяни & 75,00 & 18,75 & 6,25 & 0,00 & 0,00 & 100 \\
\hline Інші & 90,0 & 0,00 & 10,0 & 0,00 & 0,00 & 100 \\
\hline Усього & 57,66 & 14,83 & 22,01 & 4,07 & 1,44 & 100 \\
\hline
\end{tabular}

*сформовано авторами за результатами опитування

У національному розрізі серед досліджуваної вибірки найбільша частка осіб з вищою освітою це словаки $(80 \%)$, росіяни $(75 \%)$, українці $(61,1 \%)$. Найменша частка осіб з вищою освітою серед ромів - усього $6,67 \%$.

Варто наголосити, що абсолютна більшість ромів вибірки має початкову освіту $(56,67 \%)$, загальну середню - 26,67\%, ПТУ або середню спеціальну - $10 \%$, що засвідчує про загалом низьке значення об“єктивних показників компоненти «освіта» у формуванні якості життя даного етносу. Слід зазначити, що тільки роми вказали наявність початкового рівня освіти (56,67\% респондентів - ромів), що формує усю частку осіб з цим рівнем освіти у сукупній вибірці $(4,07 \%)$.

Для оцінки гендерних чинників впливу рівня освіти різних національностей на окремі аспекти якості життя досліджено статеву структуру вибірки (табл. 2):

- серед чоловіків вищу освіту здобули $58,19 \%$ (в т.ч. більше середнього значення рівень вищої освіти в українців $-66,1 \%$, росіян $-66,7 \%$, угорців - 60,0\%), ПТУ або середню спеціальну $13,56 \%$, загальну середню освіту - 21,47\%, початкову освіту $-5,65 \%$, науковий ступінь має $1,13 \%$ респондентів;

- серед жінок спостерігається наступний розподіл рівня освіти - вищу освіту здобуло $57,26 \%$ (в т.ч. більше середнього значення рівень вищої освіти мають росіянки $-85,7 \%$ та словачки - 84,6\%), ПТУ або середню спеціальну $-15,77 \%$, загальну середню - 22,41\%, початкову $-2,9 \%$ та мають науковий ступінь $-1,66 \%$. 
Статева структура окремих національностей за рівнем освіти, \%*

\begin{tabular}{|c|c|c|c|c|c|c|c|}
\hline \multirow{2}{*}{ Нац-ть } & \multirow{2}{*}{$\stackrel{\vec{E}}{\tilde{U}}$} & \multicolumn{5}{|c|}{ Рівень освіти } & \multirow[b]{2}{*}{ Разом } \\
\hline & & $\begin{array}{l}\text { Вища } \\
\text { освіта }\end{array}$ & $\begin{array}{l}\text { ПТУ, середня } \\
\text { спеціальна }\end{array}$ & $\begin{array}{l}\text { Загальна } \\
\text { середня }\end{array}$ & $\begin{array}{l}\text { Початкова } \\
\text { освіта }\end{array}$ & $\begin{array}{l}\text { Науковий } \\
\text { ступінь }\end{array}$ & \\
\hline \multirow[t]{2}{*}{ Українці } & чол & 66,06 & 13,76 & 19,27 & 0,00 & 0,92 & 100,00 \\
\hline & жін & 57,34 & 15,38 & 25,17 & 0,00 & 2,10 & 100,00 \\
\hline \multirow[t]{2}{*}{ Угорці } & чол & 60,0 & 20,0 & 20,0 & 0,0 & 0,0 & 100,00 \\
\hline & жін & 53,33 & 20,00 & 24,44 & 0,00 & 2,22 & 100,00 \\
\hline \multirow{2}{*}{ Румуни } & чол & 50,0 & 10,0 & 30,0 & 0,0 & 10,0 & 100,00 \\
\hline & жін & 53,33 & 13,33 & 33,33 & 0,00 & 0,00 & 100,00 \\
\hline \multirow[t]{2}{*}{ Словаки } & чол & 50,0 & 0,00 & 50,0 & 0,0 & 0,0 & 100,00 \\
\hline & жін & 84,62 & 15,38 & 0,00 & 0,00 & 0,00 & 100,00 \\
\hline \multirow[t]{2}{*}{ Роми } & чол & 5,56 & 5,56 & 33,33 & 55,56 & 0,00 & 100,00 \\
\hline & жін & 8,33 & 16,67 & 16,67 & 58,33 & 0,00 & 100,00 \\
\hline \multirow[t]{2}{*}{ Росіяни } & чол & 66,67 & 22,22 & 11,11 & 0,00 & 0,00 & 100,00 \\
\hline & жін & 85,71 & 14,29 & 0,00 & 0,00 & 0,00 & 100,00 \\
\hline \multirow{2}{*}{ Інші } & чол & 75,00 & 0,00 & 25,00 & 0,00 & 0,00 & 100,00 \\
\hline & жін & 100,00 & 0,00 & 0,00 & 0,00 & 0,00 & 100,00 \\
\hline \multirow[t]{2}{*}{ Усього } & чол & 58,19 & 13,56 & 21,47 & 5,65 & 1,13 & 100,00 \\
\hline & жін & 57,26 & 15,77 & 22,41 & 2,90 & 1,66 & 100,00 \\
\hline
\end{tabular}

*сформовано авторами за результатами опитування

Аналіз загальної вибірки засвідчує подібну статеву структуру респондентів за окремими рівнями освіти, хоча спостерігається незначне переважання частки чоловіків 3 вищою освітою серед українців та угорців, і навпаки, певне переважання частки жінок 3 вищою освітою зафіксовано серед словаків та росіян.

3 урахуванням демографічних тенденцій останніх років, масової трудової міграції, переорієнтації суспільства на більш утилітарні

підходи, зміни суспільних пріоритетів та послаблення значення освіти загалом, вважаємо важливим дослідити освітній рівень у розрізі вікової структури вибірки. Аналіз даних дозволяє стверджувати, що респонденти до 25 років складають $37,2 \%, 25$ - 44 роки - 40,07\% вибірки, 45 - 59 років - 16,51\%, вікова категорія 60 - 75 роки $-4,78 \%$, а вікова категорія більше 75 років складає 0,72\% вибірки(табл. 3).

Вікова структура респондентів за рівнем освіти, \%*

\begin{tabular}{|l|r|r|r|r|r|r|}
\hline \multirow{2}{*}{ Рівень освіти } & \multicolumn{7}{|c|}{ Частка, \% } \\
\cline { 2 - 7 } & \multicolumn{1}{|c|}{ до 25 p. } & \multicolumn{7}{|c|}{$25-44$ p. } & \multicolumn{1}{|c|}{$45-59$ p. } & $60-74$ p. & вище 75 p & Разом \\
\hline Вища освіта & 28,22 & 54,77 & 13,28 & 3,73 & 0,00 & 100,00 \\
\hline ПТУ, середня спеціальна & 33,87 & 29,03 & 32,26 & 3,23 & 1,61 & 100,00 \\
\hline Загальна середня & 68,48 & 8,70 & 15,22 & 5,43 & 2,17 & 100,00 \\
\hline Початкова освіта & 23,53 & 41,18 & 17,65 & 17,65 & 0,00 & 100,00 \\
\hline Науковий ступінь & 0,00 & 83,33 & 0,00 & 16,67 & 0,00 & 100,00 \\
\hline Усього & $\mathbf{3 7 , 3 2}$ & $\mathbf{4 0 , 6 7}$ & $\mathbf{1 6 , 5 1}$ & $\mathbf{4 , 7 8}$ & $\mathbf{0 , 7 2}$ & $\mathbf{1 0 0 , 0}$ \\
\hline
\end{tabular}

*сформовано авторами за результатами опитування

У групі осіб 3 вищою освітою домінують респонденти віком 25-44 роки - 54,8\% вибірки, які $€$ найбільш активними в реалізації свого соціального та економічного потенціалу. Серед осіб 3 професійно-технічною та середньою спеціальною освітою дві вікові групи мають

приблизно однакому частку - особи до 25 років $(33,9 \%)$ та $45-59$ років $(32,3 \%)$. Очевидно, що серед респондентів віком до 25 років переважають $(68,5 \%)$ особи 3 загальною середньою освітою, оскільки частина 3 них продовжує навчання у закладах вищої або 
професійної освіти, і вказує закінчену загальну середню освіту.

Важливим індикатором, що характеризує компоненту «освіта» $€$ рівень задоволення своєю освітою, який у середньому по вибірці складає 6,83 бали (за 10 бальною шкалою, де 1 - дуже не задоволений, 10 - дуже задоволений) (табл. 4).

Варто наголосити, що зазначений показник $\epsilon$ дуже суб‘ єктивним i залежить від сприйняття конкретною особою певної ситуації та навколишнього середовища у даний період часу.

Таблиця 4

Структура рівня задоволення респондентів свосю освітою, \%*

\begin{tabular}{|c|c|c|c|c|c|c|c|}
\hline \multirow{2}{*}{ Національність } & \multicolumn{4}{|c|}{ Бали, \% } & \multirow{2}{*}{$\begin{array}{l}\text { Не визна- } \\
\text { чилися, \% }\end{array}$} & \multirow{2}{*}{$\begin{array}{l}\text { Рaзом, } \\
\%\end{array}$} & \multirow{2}{*}{$\begin{array}{l}\text { Середній } \\
\text { бал } \\
\end{array}$} \\
\hline & $10-9$ & $8-6$ & $3-5$ & $1-2$ & & & \\
\hline Українці & 31,75 & 41,27 & 20,63 & 3,57 & 2,78 & 100,00 & 7,2 \\
\hline Угорці & 31,43 & 27,14 & 25,71 & 7,14 & 8,57 & 100,00 & 6,8 \\
\hline Румуни & 24,00 & 32,00 & 40,00 & 4,00 & 0,00 & 100,00 & 6,32 \\
\hline Словаки & 33,33 & 60,00 & 0,00 & 6,67 & 0,00 & 100,00 & 7,6 \\
\hline Роми & 3,33 & 6,67 & 6,67 & 70,00 & 13,33 & 100,00 & 2,04 \\
\hline Росіяни & 50,00 & 37,50 & 6,25 & 0,00 & 6,25 & 100,00 & 8,26 \\
\hline Інші & 70,00 & 20,00 & 10,00 & 0,00 & 0,00 & 100,00 & 8,4 \\
\hline Разом & 30,86 & 35,89 & 20,10 & 8,85 & 4,31 & 100,00 & 6,83 \\
\hline
\end{tabular}

*сформовано авторами за результатами опитування

У розрізі національностей найвищий середній рівень задоволення освітою в росіян - 8,26, словаків - 7,6, українців - 7,2 бали, найменший рівень задоволення своєю освітою - у ромів усього 2,04 бали, що дає підстави стверджувати про низьку суб“єктивну оцінку даним етносом компоненти «освіта» у показниках якості життя.

Варто зазначити, що дуже добре (на 9-10 балів) оцінили рівень своєї освіти 50\% росіян, 33,3\% словаків, $31,75 \%$ українців, $31,43 \%$ угорців. Дуже незадоволеними (1-2 бали) своєю освітою є роми $-70 \%$, угорці $-7,14 \%$, словаки $-6,67 \%$.

Загалом, можна стверджувати, що середній рівень задоволення своєю освітою $є$ досить високим у всіх національностей регіону, за винятком ромів.

3 точки зору оцінки ефективності системи освіти важливим індикатором іiі якості є рівень працевлаштування, затребуваності фахівців на ринку праці та частка безробітних за відповідними рівнями освіти (табл. 5).

Аналіз даних таблиці дає підстави стверджувати, що загалом 93,1\% вибірки є працевлаштованими особами, особами поза трудовим віком (пенсіонерами), студентами i тільки $6,9 \%$ - безробітними.

У розрізі окремих національностей більше $90 \%$ осіб є працевлаштованими серед українців, угорців, румун, росіян. Варто зауважити, що саме серед ромів найбільшою $\epsilon$ частка офіційно безробітних осіб - 36,67\% (серед них - 54,5\% особи 3 початковою освітою), що підтверджує тезу про досить низький рівень легальної економічної активності та трудової інтегрованості даного етносу у регіональні системи соціально-трудових відносин.

Структура стану працевлаштування за рівнем освіти представників окремих

Таблиця 5 національностей Закарпатської області, \%*

\begin{tabular}{|c|c|c|c|c|c|c|c|}
\hline \multirow[b]{2}{*}{ Націон-ть } & \multicolumn{6}{|c|}{ Частка за рівнем освіти, \% } & \multirow{2}{*}{$\begin{array}{c}\text { Усього } \\
\text { вибірка, \% }\end{array}$} \\
\hline & $\begin{array}{l}\text { Вища } \\
\text { освіта }\end{array}$ & ПТУ, середня спец. & $\begin{array}{l}\text { Загальна } \\
\text { середня }\end{array}$ & $\begin{array}{l}\text { Почат- } \\
\text { кова }\end{array}$ & $\begin{array}{l}\text { Науковий } \\
\text { ступінь }\end{array}$ & Разом & \\
\hline & \multicolumn{6}{|c|}{ Самозайняті особи, студенти, пенсіонери } & \\
\hline Українці & 60,41 & 14,69 & 23,27 & 0,00 & 1,63 & 100,0 & $\mathbf{9 7 , 2 2}$ \\
\hline Угорці & 60,00 & 16,92 & 21,54 & 0,00 & 1,54 & 100,0 & 92,86 \\
\hline Румуни & 50,00 & 12,5 & 33,33 & 0,00 & 4,17 & 100,0 & 96,00 \\
\hline Словаки & 84,62 & 7,69 & 7,69 & 0,00 & 0,00 & 100,0 & 86,67 \\
\hline Роми & 5,26 & 10,53 & 26,32 & 57,89 & 0,00 & 100,0 & 63,33 \\
\hline Росіяни & 75,00 & 18,75 & 6,25 & 0,00 & 0,00 & 100,0 & 100,00 \\
\hline Інші & 85,71 & 0,00 & 14,29 & 0,00 & 0,00 & 100,0 & 70,00 \\
\hline Усього & 58,87 & 14,40 & 22,37 & 2,83 & 1,54 & 100,0 & 93,06 \\
\hline
\end{tabular}


продовження таблиці 5

\begin{tabular}{|c|c|c|c|c|c|c|c|}
\hline \multirow[b]{2}{*}{ Націон-ть } & \multicolumn{6}{|c|}{ Частка за рівнем освіти, \% } & \multirow{2}{*}{\begin{tabular}{|c|} 
Усього \\
вибірка, \%
\end{tabular}} \\
\hline & $\begin{array}{l}\text { Вища } \\
\text { освіта }\end{array}$ & ПТУ, середня спец. & $\begin{array}{l}\text { Загальна } \\
\text { середня }\end{array}$ & $\begin{array}{l}\text { Почат- } \\
\text { кова }\end{array}$ & $\begin{array}{l}\text { Науковий } \\
\text { ступінь }\end{array}$ & Разом & \\
\hline & \multicolumn{6}{|c|}{ Безробітні особи } & \\
\hline Українці & 85,71 & 14,29 & 0,00 & 0,00 & 0,00 & 100,0 & 2,78 \\
\hline Угорці & 0,00 & 60,00 & 40,00 & 0,00 & 0,00 & 100,0 & 7,14 \\
\hline Румуни & 100 & 0,00 & 0,00 & 0,00 & 0,00 & 100,0 & 4,00 \\
\hline Словаки & 50,00 & 50,00 & 0,00 & 0,00 & 0,00 & 100,0 & 13,33 \\
\hline Роми & 9,09 & 9,09 & 27,27 & 54,55 & 0,00 & 100,0 & 36,67 \\
\hline Росіяни & 0,00 & 0,00 & 0,00 & 0,00 & 0,00 & 0,00 & $\mathbf{0 , 0 0}$ \\
\hline Інші & 100 & 0,00 & 0,00 & 0,00 & 0,00 & 100,0 & 30,00 \\
\hline Усього & 41,38 & 20,69 & 17,24 & 20,69 & 0,00 & 100,0 & 6,94 \\
\hline
\end{tabular}

* сформовано авторами за результатами опитування

У структурі зайнятих осіб, пенсіонерів та студентів, особи 3 вищою освітою складають $58,9 \%$, ПТУ і середньою спеціальною - $14,4 \%$, що підтверджує високий професійний рівень трудових ресурсів регіону.

Показовим при дослідженні структури безробітних за рівнем освіти $\epsilon$ той факт, що вищу освіту з них має 41,4\%, ПТУ, середню спеціальну та початкову - по $20,7 \%$, загальну середню $17,2 \%$. Таким чином, близько $62 \%$ безробітних респондентів є особами 3 вищою, професійною або спеціальною освітою. Слід акцентувати увагу на надзвичайно високій $(85,7 \%)$ частці безробітних з вищою освітою серед українців та $100 \%$ - серед румун. 3 вищезазначеного випливає, що номінальний факт здобуття вищої освіти не гарантує гідного працевлаштування 3 достатнім рівнем оплати праці або ефективної реалізації особистих підприємницьких ідей. Тому, для збереження працездатних і кваліфікованих людських ресурсів в регіоні, важливо створити доступні можливості для перенавчання, надати доступ для дешевих фінансових ресурсів, забезпечити організаційний та інформаційний супровід для максимального включення цих осіб у регіональні трудові відносини. Доцільно більш активно запроваджувати методики перенавчання для осіб середнього та зрілого віку, слідкувати за динамікою потреб регіонального ринку праці, навчати безробітних осіб новітнім технологіям та засобам праці, популяризувати традиційні види трудової діяльності, в т.ч. через національні спільноти.

Варто наголосити, що у сучасних динамічних умовах розвитку технологій, суцільної комп'ютеризації та діджиталізації виробничих й управлінських процесів, організаційних зв'язків, появи нових сервісів та послуг важливим $\epsilon$ постійне підвищення кваліфікації, навчання та здобуття нових знань та навичок (табл. 6.).

Таблиця 6

Структура відповідей на питання «Чи проходили ви за останній рік навчання?»*

\begin{tabular}{|l|c|c|c|c|}
\hline \multirow{2}{*}{ Національність } & \multicolumn{4}{|c|}{ Частка, \% } \\
\cline { 2 - 5 } & $\begin{array}{l}\text { Так, повязане 3 } \\
\text { професійною сферою }\end{array}$ & $\begin{array}{l}\text { Так, не повязане 3 } \\
\text { професійною сферою }\end{array}$ & Hi & Разом \\
\hline Українці & 37,70 & 12,70 & 49,60 & $\mathbf{1 0 0 , 0}$ \\
\hline Угорці & 30,00 & 8,57 & 61,43 & $\mathbf{1 0 0 , 0}$ \\
\hline Румуни & 44,00 & 20,00 & 36,00 & $\mathbf{1 0 0 , 0}$ \\
\hline Словаки & 66,67 & 6,67 & 26,67 & $\mathbf{1 0 0 , 0}$ \\
\hline Роми & 3,33 & 0,00 & 96,67 & $\mathbf{1 0 0 , 0}$ \\
\hline Росіяни & 25,00 & 6,25 & 68,75 & $\mathbf{1 0 0 , 0}$ \\
\hline Інші & 30,00 & 10,00 & 60,00 & $\mathbf{1 0 0 , 0}$ \\
\hline Усього & 34,69 & 11,00 & 54,31 & $\mathbf{1 0 0 , 0}$ \\
\hline
\end{tabular}

*сформовано авторами за результатами опитування 
Серед респондентів 34,69\% зазначили, що вони проходили за останній рік навчання, пов'язане 3 професійною діяльністю, а $11 \%$ навчання, не пов'язане з професійною діяльністю (у національному вимірі два зазначені види навчання активно використовували - словаки $(73,3 \%)$, румуни $(64 \%)$, українці $(50,4 \%)$, а найменше - роми $(3,33 \%))$. Відповідно, не проходили навчання або підвищення кваліфікації протягом останнього року $54,3 \%$ вибірки, що свідчить про досить низьку мотивацію до професійного зростання, підтримання та вдосконалення своїх знань та навичок серед респондентів. Найбільша частка осіб, які не проходили навчання протягом останнього року серед ромів $(96,7 \%)$, росіян $(68,8 \%)$ та угорців $(61,4 \%)$.

Для оцінки впливу освіти на окремі аспекти якості життя досліджено рівень суб' єктивного задоволення респондентів такими аспектами якості життя, як стан здоров'я, рівень доходів та фінансове становище, робота, суспільне життя (табл. 7).

Таблиця 7

Рівень задоволення респондентів окремими сферами життя, бал *

\begin{tabular}{|l|r|l|c|c|c|c|}
\hline $\begin{array}{l}\text { Рівень освіти/ } \\
\text { Сфери якості життя }\end{array}$ & $\begin{array}{l}\text { Вища } \\
\text { освіта }\end{array}$ & $\begin{array}{l}\text { ПТУ, } \\
\text { середня } \\
\text { спец. }\end{array}$ & $\begin{array}{l}\text { Загальна } \\
\text { середня }\end{array}$ & $\begin{array}{l}\text { Початкова } \\
\text { освіта }\end{array}$ & $\begin{array}{l}\text { Наук. } \\
\text { ступінь }\end{array}$ & $\begin{array}{l}\text { Середній } \\
\text { бал }\end{array}$ \\
\hline $\begin{array}{l}\text { Загальна задоволеність } \\
\text { життям (усі аспекти) }\end{array}$ & 6,5 & 5,8 & 6,2 & 2,5 & 8,0 & $\mathbf{6 , 2}$ \\
\hline Задоволеність освітою & 7,4 & 6,2 & 6,4 & 1,7 & 8,3 & $\mathbf{6 , 8}$ \\
\hline $\begin{array}{l}\text { Задоволеність станом } \\
\text { здоров'я }\end{array}$ & 7,4 & 7,1 & 7,0 & 2,3 & 7,8 & $\mathbf{7 , 1}$ \\
\hline $\begin{array}{l}\text { Задоволеність рівнем доходів } \\
\text { і фінансовим становищем }\end{array}$ & 5,6 & 4,9 & 5,0 & 1,2 & 6,0 & $\mathbf{5 , 4}$ \\
\hline Задоволеність роботою & 7,4 & 5,9 & 6,9 & 1,6 & 8,0 & $\mathbf{6 , 9}$ \\
\hline $\begin{array}{l}\text { Задоволеність суспільним } \\
\text { життям }\end{array}$ & 7,1 & 5,7 & 7,2 & 1,4 & 7,8 & $\mathbf{6 , 8}$ \\
\hline
\end{tabular}

*сформовано авторами за результатами опитування

Із запропонованих аспектів якості життя за суб'єктивними оцінками досліджуваної групи респондентів, найвищим $\epsilon$ середній рівень задоволення здоров'ям (7,1 бали), дещо меншим $\epsilon$ рівень задоволення роботою (6,9 бала), освітою (6,8 бала) та суспільним життям (6,8 бала). Найнижчим $є$ задоволення респондентів своїм рівнем доходів (5,4 бала), що очікувано в умовах постійного скорочення реальних доходів населення, підвищення рівня споживчих цін та вартості комунальних послуг при одночасній відсутності дієвих інструментів підтримки різних соціальних верств (пенсіонери, багатодітні сім'ї, молоді фахівці, підприємці).

Зазначена інформація дає підстави стверджувати, що особи 3 вищою освітою та науковим ступенем мають вищий суб'єктивний рівень задоволення усіма досліджуваними аспектами якості життя, що визначається дещо ширшим світоглядом, відносно вищим рівнем доходів, кращим вмінням практичного використання наявної інформації та можливостей для задоволення потреб у різних сферах життя.

Висновки та перспективи подалыших досліджень. Результати аналізу сучасних підходів українських та зарубіжних науковців до визначення та компонування поняття «якість життя» засвідчує про суттєву диференціацію у переліку об'єктивних індикаторів та високий рівень суб'єктивізму при оцінювання окремих складових цієї концепції.

Підсумовуючи дослідження національної структури респондентів Закарпатської області за рівнем освіти варто зазначити про достатньо високий рівень вищої (в межах $80-52 \%$ конкретної національності) та професійнотехнічної та спеціальної (в межах $20-10 \%$ конкретної національності) освіти для усіх національностей, за винятком ромів. Вивчення статевої структури національностей за рівнем освіти не виявило суттєвих гендерних особливостей. Абсолютна більшість опитаних $(94,3 \%)$ - це особи активного працездатного віку (до 60 років). Результати дослідження підтвердили високий фаховий рівень трудових ресурсів регіону, оскільки у середньому $74 \%$ зайнятих осіб мають вищу або професійно технічну, спеціалізовану освіту. Варто наголосити, що серед безробітних високою $\epsilon$ частка осіб $з$ вищою та професійно-технічною $\mathrm{i}$ спеціальною освітою $(62,1 \%)$, що вимагає створення доступних можливостей для постійного підвищення кваліфікації або перенавчання осіб різних національностей, які вже не відповідають сучасним вимогам ринку праці. 
Проведене дослідження засвідчило, що у респондентів 3 вищою освітою та науковим ступенем кращий рівень суб'єктивного задоволення такими аспектами якості життя, як стан здоров'я, рівень доходів та фінансове становище, робота, суспільне життя.

Подальші дослідження доцільно приділити виробленню інструментарію (національного, регіонального рівня) для підвищення рівня задоволення потреб усіх національностей регіону у різних аспектах якості життя. Одним з напрямів досягнення цього завдання $\epsilon$ впровадження доступної, цілісної, постійно діючої системи професійного та особистісного навчання, підвищення кваліфікації, адаптації осіб середнього та зрілого віку до нових технічних та технологічних можливостей, пов'язаних 3 активним розвитком інформаційного суспільства

\section{СПИСОК ВИКОРИСТАНИХ ДЖЕРЕЛ}

1. Jirava P., Mandys J., Kasparova M., Krupka J.. System Approach to Determinants of Quality of Life within a Region. WSEAS transactions on systems. - 2010. - Issue 3, Volume 9, pp. $243-252$

2. Flanagan J.C. A research approach to improving our quality of life. American Psychologist . - 1978. - 33, pp. 138-147.

3. J. Brown, A. Bowling, T. Flynn. Models of Quality of Life: A Taxonomy, Overview and Systematic Review of the Literature. Review. $-2004 .-102$ p.

4. Human Development. Report 2019. Beyond income, beyond averages, beyond today: Inequalities in human development in the 21 st century. UNDP. - 2019. - 366 p. - Електронний ресурс. - режим доступу: http://hdr.undp.org/sites/default/files/hdr2019.pdf.

5. The Legatum Prosperity Index.2019. Електронний ресурс. - режим доступу: https://www.prosperity.com/rankings

6. Національна доповідь про стан і перспективи розвитку освіти в Україні / [Нац. акад. пед. наук України / за заг. ред. В. Г. Кременя]. — Київ: Педагогічна думка, 2016. - 448 с.

7. Лібанова Е.М., Гладун О.М., Лісогор Л.С. Вимірювання якості життя в Україні. Аналітична доповідь. К.: Інститут демографії та соціальних досліджень імені М.В. Птухи НАН України, Програма Розвитку ООН, Міністерство економічного розвитку і торгівлі України, 2013. - 50 с.

8. І.В. Гукалова. Якість життя населення України: суспільно-географічна концептуалізація. Монографія. К. - 2009. - Електронний ресурс. - режим доступу: https://igu.org.ua > sites > default > files > pdf-text > life-quality

9. Матеріали наукового проекту «Якість життя населення регіону в етнодемографічному вимірі». -2019 p.

\section{REFERENCES}

1. Jirava P., Mandys J., Kasparova M., Krupka J. (2010) System Approach to Determinants of Quality of Life within a Region. WSEAS transactions on systems, Issue 3, Volume 9, pp. 243 - 252. [in English].

2. Flanagan J.C. (1978.) A research approach to improving our quality of life. American Psychologist . 33 (2), pp. 138-147. [in English].

3. Brown J., Bowling A., Flynn T. (2004.) Models of Quality of Life: A Taxonomy, Overview and Systematic Review of the Literature. (Project Report) European Forum on Population Ageing Research. 102 p. [in English].

4. UNDP (2019) Human Development. Report 2019. Beyond income, beyond averages, beyond today: Inequalities in human development in the 21st century. 366 p. Retrived from: http://hdr.undp.org/sites/default/files/hdr2019.pdf. [in English].

5. The Legatum Institute (2019) The Legatum Prosperity Index.2019. Retrived from: https://www.prosperity.com/rankings. [in English].

6. Nats. akad. ped. nauk Ukrayiny (2016) Natsional'na dopovid' pro stan i perspektyvy rozvytku osvity v Ukrayini . [National report on the state and prospects of education in Ukraine] / za zah. red. V. H. Kremenya. - Kyyiv: Pedahohichna dumka, 448 p. [in Ukrainian].

7. Libanova E.M., Hladun O.M., Lisohor L.S. (2013) Vymiryuvannya yakosti zhyttya v Ukrayini, Analitychna dopovid'. [Measuring the quality of life in Ukraine. Analytical report.] K.: Instytut demohrafiyi ta sotsial'nykh doslidzhen' imeni M.V. Ptukhy NAN Ukrayiny, Prohrama Rozvytku OON, Ministerstvo ekonomichnoho rozvytku i torhivli Ukrayiny, 50 p. [in Ukrainian].

8. I.V. Hukalova (2009) Yakist' zhyttya naselennya Ukrayiny: suspil'no-heohrafichna kontseptualizatsiya. [Quality of life of the population in Ukraine: socio-geographical conceptualization.]. K. Retrived from: https://igu.org.ua > sites > default > files > pdf-text > life-quality. [in Ukrainian].

9. Materialy naukovoho proektu «Yakist' zhyttya naselennya rehionu v etnodemohrafichnomu vymiri» (2019). [in Ukrainian] (unpublished). 